\title{
Effect of ranitidine bismuth citrate on postprandial plasma gastrin and pepsinogens
}

\author{
A G Fraser, W M Lam, Y W Luk, J Sercombe, A M Sawyerr, M Hudson, I M Samloff, \\ R E Pounder
}

\begin{abstract}
Ranitidine bismuth citrate was compared with an equipotent dose of ranitidine, to determine whether the former, by an anti-Helicobacter pylori activity, would counteract the rise of gastrin resulting from ranitidine's gastric acid antisecretory activity. Twenty four men with duodenal ulcers were studied before and on the 8th day of dosing with either ranitidine bismuth citrate $800 \mathrm{mg}$ twice daily or ranitidine $300 \mathrm{mg}$ twice daily (double blind, randomised, parallel groups). Fasting and postprandial plasma gastrin and plasma pepsinogen I and II concentrations were measured, and a ${ }^{13} \mathrm{C}$-urea breath test was performed before and on the 8th day of dosing. The ${ }^{13} \mathrm{C}$-urea breath tests were positive in 21 patients before dosing and remained positive in nine of nine of the ranitidine dosed patients, whereas only two of 12 patients treated with ranitidine bismuth citrate remained positive. The expected rise in meal stimulated plasma gastrin with ranitidine was seen in the 12 patients who received ranitidine but, despite suppression of $\boldsymbol{H}$ pylori urease activity in 10 of 12 patients taking ranitidine bismuth citrate, there was no attenuation of the meal stimulated gastrin rise. There was no significant difference in the mean derived (4 hour) plasma pepsinogen I and II concentrations after dosing with ranitidine or ranitidine bismuth citrate.

(Gut 1993; 34: 338-342)
\end{abstract}

Ranitidine bismuth citrate is a bismuth compound with gastric acid antisecretory activity'; the drug is formed by reacting ranitidine with bismuth citrate. Treatment with $\mathrm{H}_{2}$ receptor antagonists at conventional doses results in a modest increase in the plasma gastrin concentration; for example, dosing with ranitidine $300 \mathrm{mg}$ at night resulted in a $58 \%$ increase in the 24 hour integrated plasma gastrin concentration on the 7 th day of dosing. ${ }^{2}$ Higher doses cause a greater increase in the 24 hour plasma gastrin concentration inversely proportional to the antisecretory effect; for example, on the 7 th day of dosing with ranitidine $300 \mathrm{mg}$ twice daily, the 24 hour plasma gastrin concentration increased by $165 \%$ compared with baseline. ${ }^{3}$ Ranitidine bismuth citrate is being developed, among other indications, for the treatment of duodenal ulcer patients most of whom have Helicobacter pylori in their gastric mucosa. ${ }^{+} H$ pylori infection is associated with a reversible increase in the 24 hour plasma gastrin concentration $^{5}$ and plasma pepsinogen I (PG I) and pepsinogen II (PG II) concentration. ${ }^{67}$ The postprandial plasma gastrin response and the raised
PG I and PG II concentrations are reduced by eradication of $H$ pylori. ${ }^{72}$ Most bismuth compounds have significant inhibitory effects on $H$ pylori, although eradication is uncommon after dosing with bismuth alone. ${ }^{13}$ The object of the present study was to compare the effect of dosing with either ranitidine, or ranitidine bismuth citrate, on postprandial gastrin and pepsinogen release in $H$ pylori infected duodenal ulcer patients.

\section{Methods}

Twenty four men with a history of $H$ pylori positive duodenal ulceration, confirmed by endoscopy and antral biopsy specimens in the preceding four years were studied. Patients with other significant diseases or with a history of alcohol abuse were excluded. Patients who had received a bismuth compound within the past 3 months or an antisecretory drug within 2 weeks before the study were also excluded.

The patients were investigated using a randomised, double blind parallel group design; they were studied before and on the 8th day of dosing with either ranitidine bismuth citrate $800 \mathrm{mg}$ twice daily (GR 122311X: Glaxo Group Research Ltd, Ware, UK), or ranitidine $300 \mathrm{mg}$ twice daily (as ranitidine hydrochloride; Glaxo Group Research Ltd). Ranitidine bismuth citrate $800 \mathrm{mg}$ contains the equivalent of ranitidine $300 \mathrm{mg}$ as the hydrochloride. On each study morning, the fasting patients had a baseline blood sample of 0800 hours, followed by a standard breakfast at 0815 hours; hourly blood samples were taken until 1200 hours. The blood samples were centrifuged immediately and two plasma samples were stored at $-20^{\circ} \mathrm{C}$ for each time interval. The plasma gastrin concentration was analysed at Royal Postgraduate Medical School (Professor Bloom's laboratory) by radioimmunoassay. ${ }^{1+}$ Duplicate samples were coded and shipped in dry ice to Los Angeles where they were analysed for PG I and PG II by radioimmunoassay. ${ }^{15}$

At 1200 hours, a ${ }^{13} \mathrm{C}$-urea breath test was performed by a standard protocol. ${ }^{16}{ }^{17}$ Briefly, a baseline breath sample was taken, and the patient given $100 \mathrm{mg}$ of ${ }^{13} \mathrm{C}$-urea 10 minutes after a high fat liquid meal ( $100 \mathrm{ml})$. Exhaled breath samples were pooled in a large bag at 5 minute intervals from 10 to 40 minutes after giving the ${ }^{13} \mathrm{C}$-urea. The ratio of ${ }^{13} \mathrm{CO}_{2}$ to ${ }^{12} \mathrm{CO}_{2}$ in the baseline and post ${ }^{13} \mathrm{C}$-urea expired air samples were measured by mass spectrometry with cryogenic extraction of the $\mathrm{CO}_{2}$, using a dual inlet ratio mass spectrometer (BSIA, Brentford, Middlesex). The results for excess ${ }^{13} \mathrm{CO}_{2}$ are expressed as parts/ 1000 per $\mathrm{ml}$; the baseline pre ${ }^{13} \mathrm{C}$-urea breath 
TABLE I Patient characteristic in both groups (Values median (range))

\begin{tabular}{|c|c|c|}
\hline & $\begin{array}{l}\text { Ranitidine } \\
\text { bismuth } \\
\text { citrate group } \\
(n=12)\end{array}$ & $\begin{array}{l}\text { Ranitidine } \\
\text { group } \\
(n=12)\end{array}$ \\
\hline $\begin{array}{l}\text { Age (years) } \\
\text { Weight }(\mathrm{kg}) \\
\text { Height }(\mathrm{cm}) \\
\text { Smoking (cigarettes/day) } \\
\text { Alcohol intake (units/week) } \\
\text { Previous } \mathrm{H}_{2} \text { receptor } \\
\text { antagonist or omeprazole } \\
\text { (within last } 3-26 \text { weeks) } \\
\text { Helicobacter pylori positive at } \\
\text { time of study ('"C urea } \\
\text { breath test) }\end{array}$ & $\begin{array}{c}55^{\star}(31-64) \\
77(57-99) \\
170(155-185) \\
5(0-30) \\
4(0-16)\end{array}$ & $\begin{array}{c}37^{\star}(23-66) \\
74(62-92) \\
175(165-181) \\
2(0-25) \\
4(0-16)\end{array}$ \\
\hline
\end{tabular}

sample is subtracted from the post ${ }^{13} \mathrm{C}$-urea sample.

Plasma gastrin and plasma PGI and PGII concentrations were logarithmically transformed before analysis. Derived 4 hours weighted means were calculated using trapezoidal integration and

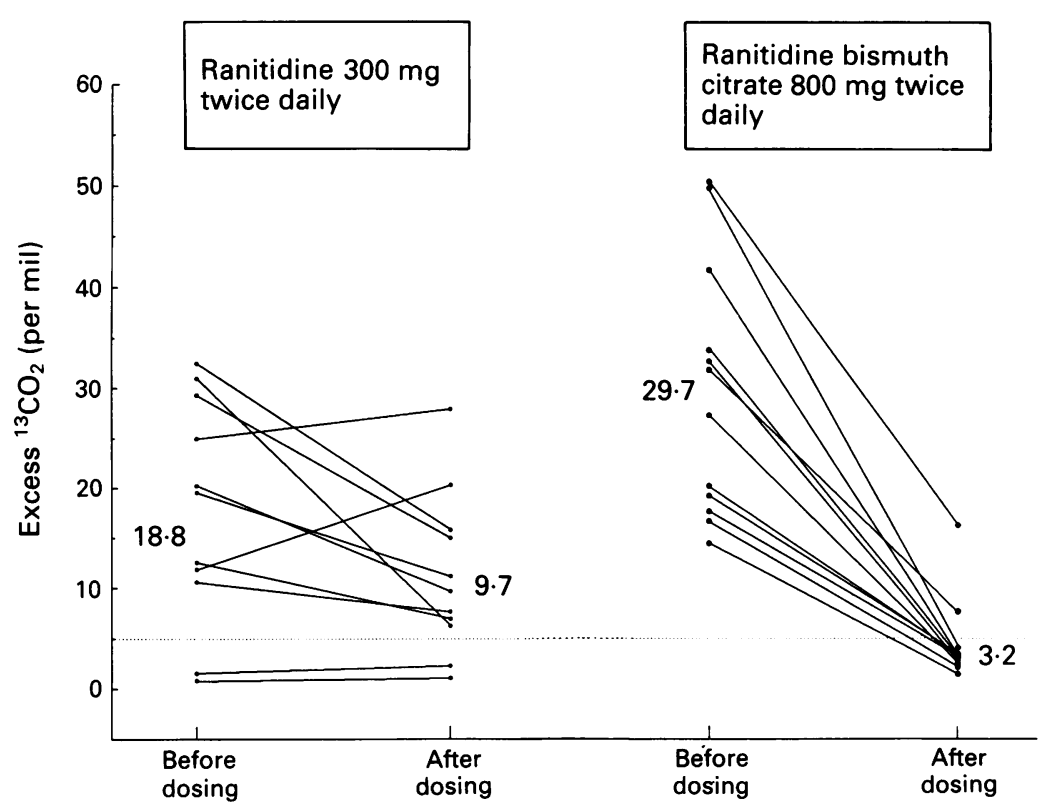

Figure 1: The excess ${ }^{13} \mathrm{CO}_{2}$ (intragastric urease activity) before and on the 8th day of dosing with either ranitidine $300 \mathrm{mg}$ twice daily or ranitidine bismuth citrate $800 \mathrm{mg}$ twice daily in 23 duodenal ulcer patients. The range for Helicobacter pylori negative subjects is below the broken line $\left(\right.$ excess $\left.{ }^{13} \mathrm{Co}_{2}<5\right)$.

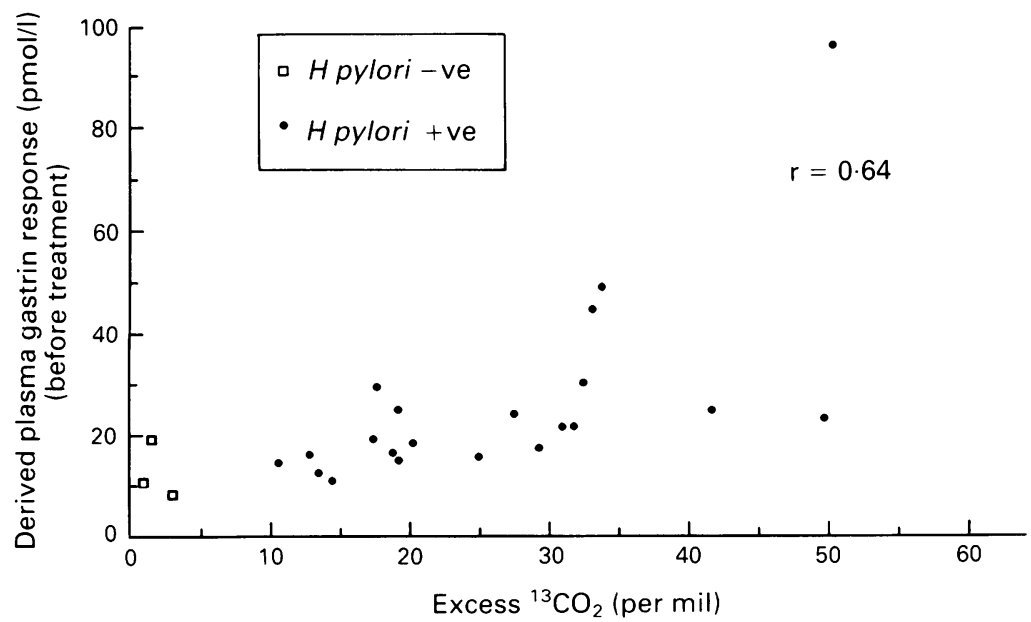

Figure 2: The correlation between the excess ${ }^{\prime} \mathrm{CO}_{2}$ before dosing and the derived 4 hour plasma gastrin concentration in 23 duodenal ulcer patients $(r=0.64, p=0.001)$. dividing the resulting area under the curve by the time interval. These responses were analysed by analysis of covariance using the pre-dose weighted mean value as the baseline covariate. The relation between the derived plasma gastrin and the ${ }^{13} \mathrm{C}$-urea breath test was examined by regression analysis. The study was approved by the Ethical Practices Subcommittee of Hampstead Health Authority, and each patient provided written, informed consent.

\section{Results}

All 24 patients completed the study. No serious adverse events were reported. Two patients taking ranitidine bismuth citrate reported minor events; one had moderate diarrhoea and associated pruritus ani and one had nausea, but neither withdrew from treatment. The demographic features of the two patient groups are described in Table I. The weight, height, alcohol intake, smoking habits, and medication (within the previous 6 months) were similar for the two groups, but there was a significant difference between the ages of the two groups $(p=0 \cdot 02)$.

Breath test results were available in only 23 patients. Twenty one patients had a positive ${ }^{13} \mathrm{C}$ urea breath test (but two patients were breath test negative and both were in the ranitidine group). One of these patients had received triple therapy unknown to the investigators and the other had a low density of $H$ pylori like bacteria in his original gastric biopsy specimen. A repeat breath test by the latter patient 4 months after the study was also negative and a repeat endoscopic biopsy specimen showed no evidence of $H$ pylori like bacteria. The ${ }^{13} \mathrm{C}$-urea breath test remained positive in all nine patients taking ranitidine $300 \mathrm{mg}$ twice daily and the ${ }^{13} \mathrm{C}$-urea breath tests in the two patients with negative tests remained negative; the median excess ${ }^{13} \mathrm{CO}_{2}$ was 18.8 (range $0.9-32.5)$ and 9.7 (0.9-27.9) before and on the 8 th day of dosing respectively (Fig 1). There was a fall in the excess ${ }^{13} \mathrm{CO}_{2}$ in all 12 patients taking ranitidine bismuth citrate; 10 of these patients had a post dosing excess ${ }^{13} \mathrm{CO}_{2}$ within the accepted range for $H$ pylori negative patients. The median excess ${ }^{13} \mathrm{CO}_{2}$ fell from $29 \cdot 7$ (range 14.4-50.4) before dosing to $3 \cdot 2(1 \cdot 4-16 \cdot 2)$ on the eight day of dosing respectively. There was a significant correlation between the predosing derived plasma gastrin response and predosing excess ${ }^{13} \mathrm{CO}_{2}$ (Fig 2, $\mathrm{r}=0.64$, $\mathrm{p}=0.001$ ).

The mean fasting plasma gastrin concentration before dosing with ranitidine was $11 \mathrm{pmol} / \mathrm{l}$ and $13.0 \mathrm{pmol} / \mathrm{l}$ on the 8 th day of dosing; the respective values before and during dosing with ranitidine bismuth citrate were 18.0 and 21.3 $\mathrm{mol} / \mathrm{l}$. The mean derived plasma gastrin response increased from $15.9 \mathrm{pmol} / \mathrm{l}$ (range $8 \cdot 2-28 \cdot 2$ ) before dosing to $26 \cdot 8 \mathrm{pmol} / \mathrm{l}$ (range $12 \cdot 8-51 \cdot 1$ ) on the 8 th day of dosing with ranitidine. The mean derived plasma gastrin response increased from 27.1 pmol/1 (range 11.0-99.3) before dosing to $39 \cdot 3 \mathrm{pmol} / \mathrm{l}$ (range $22 \cdot 5-70 \cdot 8$ ) on the eighth day of dosing with ranitidine bismuth citrate (Fig 3). Since this was a randomised, double blind study the disparity at baseline is attributed to chance. If the post treatment values 


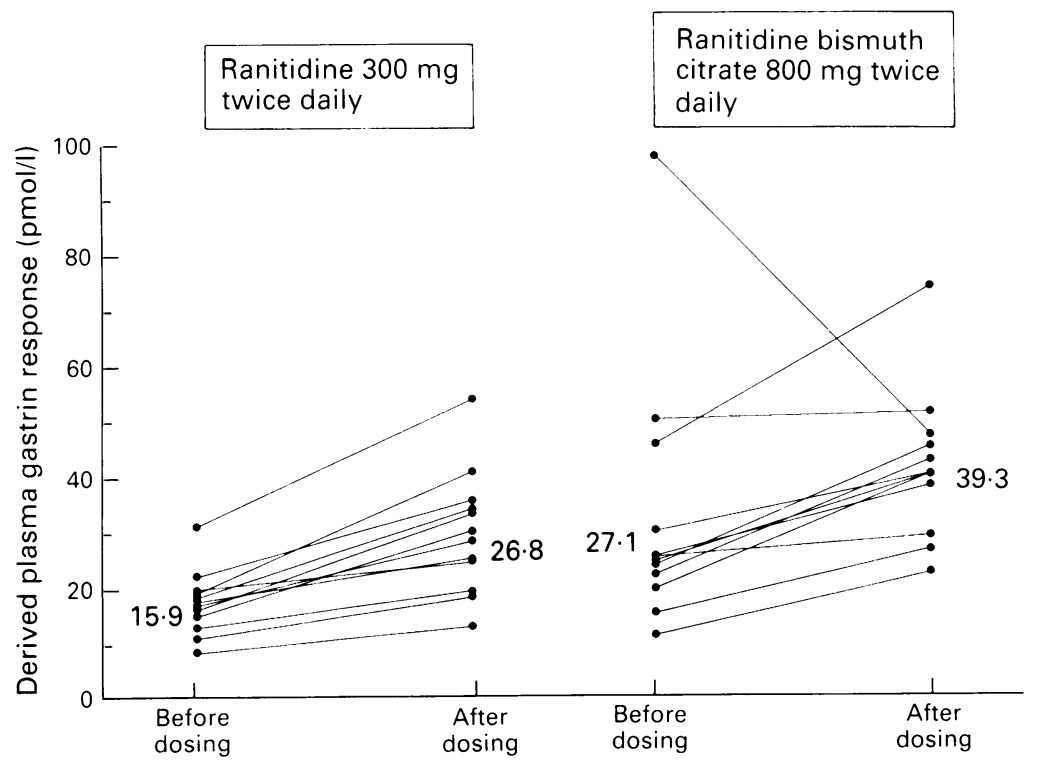

Figure 3: The derived 4 hour plasma gastrin concentration before and on the 8th day of dosing with either ranitidine $300 \mathrm{mg}$ twice daily or ranitidine bismuth citrate $800 \mathrm{mg}$ twice daily in 24 duodenal ulcer patients.

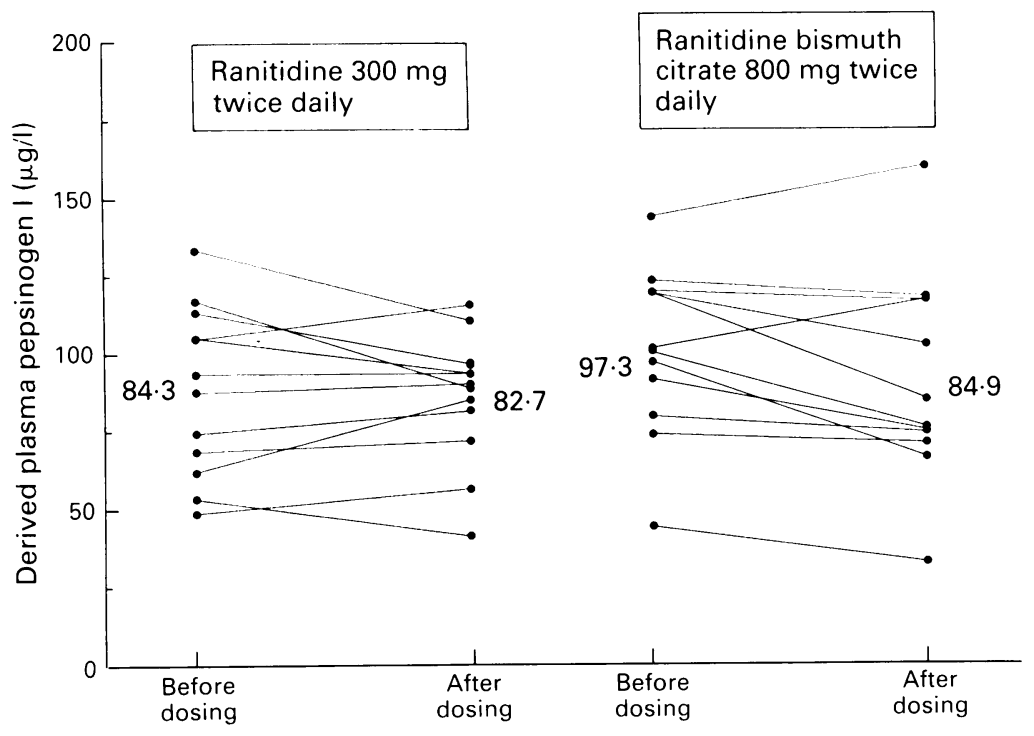

Figure 4: The derived 4 hour plasma pepsinogen I concentration before and on the 8th day of dosing with either ranitidine $300 \mathrm{mg}$ twice daily or ranitidine bismuth citrate $800 \mathrm{mg}$ twice daily in 24 duodenal ulcer patients.
The 24 patients showed a small but significant increase in the plasma PG I concentration after eating the standard breakfast. The median plasma PG I concentration rose from a baseline of $89.7 \mu \mathrm{g} / \mathrm{l}$ to $98 \cdot 0.100 \cdot 3,101 \cdot 3$, and $96.9 \mu \mathrm{g} / \mathrm{l}$ at $0900,1000,1100$, and 1200 hours, respectively $(\mathrm{p}<0.005$ for all time intervals). The mean derived plasma PG I concentration was unchanged on the 8th day of dosing with either ranitidine $300 \mathrm{mg}$ twice daily $(84.3 v 82.7 \mu \mathrm{g} / \mathrm{l})$ or ranitidine bismuth citrate $800 \mathrm{mg}$ twice daily $(97.3 v 84.9 \mu \mathrm{g} / \mathrm{l}$ (Fig 4). The ratio of the treatment response (ranitidine bismuth citrate to rantidine) was $0.90(95 \%$ CI $0.77-1.05$, p value $=0 \cdot 16$; Table II). There was no significant difference in the mean derived plasma PG II concentration after dosing with either ranitidine $(12.8 \mu \mathrm{g} / \mathrm{l}$ and $13.6 \mu \mathrm{g} / \mathrm{l}$ before and after treatment, respectively) or ranitidine bismuth citrate $(17 \cdot 3 \mu \mathrm{g} / \mathrm{l}$ and $15.9 \mu \mathrm{g} / \mathrm{l}$ before and after treatment respectively, (Figure 5). The ratio of the treatment response (ranitidine bismuth citrate to ranitidine) was $0.90(95 \% \mathrm{CI} 0.77-1.05$, p value $=0 \cdot 16$; Table IV).

\section{Discussion}

Ranitidine bismuth citrate suppresses $H$ pylori urease activity on the 8th day of dosing. All 12 patients had a significant fall in intragastric urease activity and 10 of 12 had a excess ${ }^{13} \mathrm{C}$-Urea value within the range accepted for $H$ pylorinegative subjects on the 8 th day of dosing. ${ }^{17}$ This prompt fall in intragastric urease activity seems to be similar to that achieved with other bismuth compounds. ${ }^{18}$ The systemic absorption of the bismuth in ranitidine bismuth citrate is less than after dosing with tripotassium dicitrato bismuthate. ${ }^{1819}$ The effective anti- $H$ pylor activity of ranitidine bismuth citrate, and that of more poorly absorbed bismuth compounds such as bismuth subsalicylate, suggests that systemic absorption is not required..$^{18}$ There was no significant change in the $H$ pylori urease activity after dosing with ranitidine $300 \mathrm{mg}$ twice daily for 7 days. Dosing with ranitidine resulted in the expected increase in the postprandial plasma gastrin concentration, which is consistent with, and inversely correlated to, its antisecretory activity. ${ }^{3}$ There was no significant change in the plasma PG I or PG II concentration after 7 days of dosing with ranitidine.

The expected ablation of the meal stimulated increase in plasma gastrin was not observed after dosing with ranitidine bismuth citrate. The ${ }^{13} \mathrm{C}$ urea breath test is reproducible and provides an are linearly related to predosing values, the analysis of covariance removes the effect of the ratio of ranitidine bismuth citrate to ranitidine was 1.08 ( $95 \%$ confidence intervals) (CI) 0.85 $1 \cdot 36$, p value $=0 \cdot 50$; Table II) - that is, no significant difference was observed between the groups.

TABLE II Mean plasma gastrin and pepsinogen $(P G) I$ and II concentrations before and after dosing

\begin{tabular}{|c|c|c|c|c|c|c|c|c|c|}
\hline & \multicolumn{3}{|c|}{ Plasma gastrin (pmol/l) } & \multicolumn{3}{|c|}{ Plasma PGI ( $\mu \mathrm{g} / \mathrm{l})$} & \multicolumn{3}{|c|}{ Plasma PGII $(\mu g / l)$} \\
\hline & Predose $e^{\star}$ & Postdose & $\begin{array}{l}\text { Adjusted } \\
\text { postdose }\end{array}$ & Predose & Postdose & $\begin{array}{l}\text { Adjusted } \\
\text { postdose }\end{array}$ & Predose & Postdose & $\begin{array}{l}\text { Adjusted } \\
\text { postdose }\end{array}$ \\
\hline $\begin{array}{l}\text { Ranitidine bismuth } \\
\quad \text { citrate (RBC) } \\
\text { Ranitidine } \\
\text { Ratio (RBC/ranitidine) } \\
95 \% \mathrm{CI}\end{array}$ & $\begin{array}{l}27 \cdot 1 \\
15 \cdot 9\end{array}$ & $\begin{array}{l}39 \cdot 3 \\
26 \cdot 8 \\
1 \cdot 08 \ddagger \\
(0 \cdot 85,1 \cdot 36)\end{array}$ & $\begin{array}{l}33 \cdot 8 \\
31 \cdot 3\end{array}$ & $\begin{array}{l}97 \cdot 3 \\
84 \cdot 3\end{array}$ & $\begin{array}{l}84 \cdot 9 \\
82 \cdot 7 \\
0 \cdot 95 \\
(0 \cdot 77,1 \cdot 05)\end{array}$ & $\begin{array}{l}79 \cdot 3 \\
88 \cdot 5\end{array}$ & $\begin{array}{l}17 \cdot 3 \\
12 \cdot 8\end{array}$ & $\begin{array}{l}15 \cdot 9 \\
13 \cdot 6 \\
0 \cdot 9 \star \star \\
(0 \cdot 77,1 \cdot 05)\end{array}$ & $\begin{array}{l}13 \cdot 9 \\
15 \cdot 5\end{array}$ \\
\hline
\end{tabular}

* Predose and postdose are geometric means

tadjusted postdose geometric means; adjusted to predose concentration.

$\neq \mathrm{p}=0 \cdot 50$

$\int_{\star \star} p=0 \cdot 16$
$p=0 \cdot 16$ 


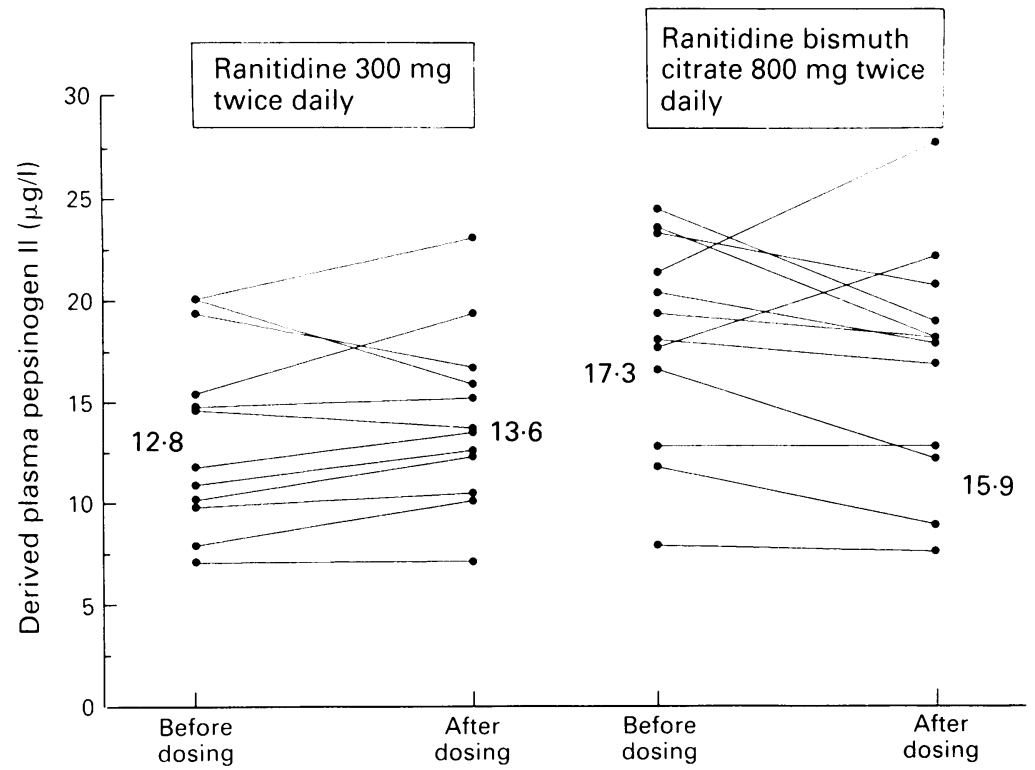

Figure 5: The derived 4 hour plasma pepsinogen II concentration before and on the 8th day of dosing with either ranitidine $300 \mathrm{mg}$ twice daily or ranitidine bismuth citrate $800 \mathrm{mg}$ twice daily in 24 duodenal ulcer patients. bismuth citrate on basal and meal stimulated PG I and II concentrations was also unexpected. '2 This absence is in contrast to the two-to four fold increase of plasma PG I after dosing with omeprazole, particularly in $H$ pylori positive subjects. ${ }^{31}{ }^{32}$ The small but delayed postprandial increase in PG I concentration was also reported by Waldum et al. ${ }^{33}$ The mechanism of this increase is also unknown; gastritis and backdiffusion of the zymogens or a direct stimulation of secretion by a bacterial product of $H$ pylori are possible explanations. ${ }^{3+35}$

The time required for the resolution of plasma gastrin to normal and the reduction of plasma pepsinogens after eradication is uncertain. The plasma gastrin and pepsinogen concentrations were significantly reduced 6 weeks after complete eradication of $H$ pylori in a study of asymptomatic $H$ pylori infected subjects ${ }^{11}{ }^{12}$ and 4 weeks after completing treatment in a study of duodenal ulcer patients, ${ }^{36}$ but had not changed 24 hours after beginning eradication treatment in another study of duodenal ulcer patients. ${ }^{29}$ More prolonged dosing with ranitidine or ranitidine bismuth citrate might have resulted in significant differences in the postprandial plasma gastrin and plasma pepsinogen concentrations.

easy, non-invasive measure for the detecti $H$ pylori, ${ }^{20}$ but a negative value while a patient is taking bismuth does not indicate that the organism has been eradicated from the gastric mucosa. ${ }^{16} 2122$ Based on the action of other bismuth compounds, it is likely that the effect of ranitidine bismuth citrate on the ${ }^{13} \mathrm{C}$-urea breath tests reflects suppression of urease activity and not eradication of the infection..$^{13}$ The present study suggests that suppression of $H$ pylori urease activity does not change the abnormal mechanism, as yet unknown, which causes the increase in the plasma gastrin concentration. This conclusion is supported by other studies which showed that when ammonia production is increased by giving an oral dose of urea, or decreased by the urease inhibitor acetohydroxamic acid, the plasma gastrin concentration does not increase or decrease respectively..$^{23}{ }^{2+}$

The $H$ pylori related increase in the plasma gastrin concentration may be caused by the presence of the bacterium (or its bacterial products), or alternatively may be the result of $H$ pylori induced gastritis, and eradication may be necessary to normalise the plasma gastrin response. $^{25}$ Bismuth compounds have a pronounced bactericidal effect against $H$ pylori both in vitro and in vivo, and the degree of gastritis lessens in most patients during a 2 to 4 week course of bismuth salicylate, ${ }^{26} 27$ but this improvement may be less than that demonstrated after eradication. ${ }^{28}$ Although Chittajallu et al showed that there was a significant reduction in the polymorphonuclear cell infiltrate in the antral mucosa 24 hours after starting tripotassium dictrato bismuthate together with metronidazole and amoxycillin, ${ }^{29}$ the chronic inflammatory infiltrate may take several months to resolve after eradication. ${ }^{30}$ This study suggests that partial resolution of the acute inflammatory infiltrate by a bismuth compound does not result in a reduction of the meal stimulated plasma gastrin response.

The lack of effect of ranitidine or ranitidine
The study was supported by a grant from Glaxo Group Research Ltd. The manuscript was prepared by Ms Doris Elliott.

1 Prewett EJ, Nwokolo CU, Hudson M, Sawyerr AM, Fraser A, Pounder RE. The effect of GR122311X, a bismuth compound with $\mathrm{H}_{2}$-antagonist activity, on 24-hour intragastric acidity. Aliment Pharmacol Ther 1991; 5: 481-90.

2 Lanzon-Miller S, Pounder RE, Chronos NAF, Raymond F, Hamilton MR, Dalgleish D. Twenty-four hour intragastric acidity and plasma gastrin concentration in healthy volunteers taking nizatidine $150 \mathrm{mg}$, nizatidine $300 \mathrm{mg}$, ranitidine $300 \mathrm{mg}$, or placebo at $2215 \mathrm{~h}$. Gut 1988; 29: 1364 9.

3 Pounder RE, Smith J. Drug-induced changes of plasma gastrin concentration. Gastroenterol Clin North Am 1990; 19: gastrin con.

4 Graham DY. Campylobacter pylori and peptic ulcer disease. Gastroenterology 1989; 96: 615-25.

5 Smith JTL, Pounder RE, Nwokolo CU, Lanzon-Miller S, Evans DG, Graham DY, et al. Inappropriate hypergastrinaemia in asymptomatic healthy subjects with Campylobacter pylori. Gut 1990; 31: 522-5.

6 Oderda G, Vaira D, Dell'Olio D, Holton J, Forni M, Altare F, et al. Serum pepsinogen I and gastrin concentrations in children positive for Helicobacter pylori. $f$ Clin Pathol 1990 43: 762-5.

7 Levi S, Beardshall K, Haddah G, Playford R, Ghosh P, Calam J. Campylobacter pylori and duodenal ulcers: The gastrin link. Lancet 1989 ; i: $1167-8$.

8 McColl KEL, Fullarton GM, Nujumi AM, MacDonald AM, Brown IL, Hilditch TE. Lowered gastrin and gastric acidity Brown IL, Hilditch TE. Lowered gastrin and gastric acidity after eradication of Cam

9 Oderda G, Vaira D, Holton J, Ainley C, Altare F, Ansaldi N. Amoxycillin plus tinidazole for Campylobacter pylori gastritis in children: assessment by serum IgG antibody, pepsinogen I, and gastrin levels. Lancet 1989; i: 691-2. FW. Serum gastrin, pepsinogen I and II in Helicobacter pylori positive gastritis and peptic ulcer: effect of bacteria eradication. Gastroenterology 1991; 100: A181.

11 Prewett EJ, Smith JTL, Nwokolo CU, Hudson M, Sawyerr AM, Pounder RE. Eradication of Helicobacter pylori abolishes 24-hour hypergastrinaemia: a prospective study in healthy 24-hour hypergastrinaemia: a prospective study in h
subjects. Aliment Pharmacol Ther 1991; 5: 283-96.

12 Fraser AG, Prewett EJ, Pounder RE, Samloff IM. Twentyfour hyperpepsinogenaemia in $H$ pylori-positive subjects is abolished by eradication of the infection. Ther 1992; 6: 389-94. GNJ. Campylobactor pyloridis-associated chronic active of antibacterial and anti-ulcer treatment. Gastroenterolog 1988; 94: 33-40

14 Bryant MG, Adrain TE. Gastrin. In: Bloom SR, Long R, eds Saunders, 1982: 51-9. mucosa and radioimmunoassay in serum. Gastroenterolog 1982; 82: 26-53.

16 Logan RPH, Polson RJ, Misiewic\% JJ, Rao G, Karim NQ, Newell D, et al. Simplified single sample "Carbon urea
10 Wagner S, Varrentrapp M, Haruma K, Gebel M, Schmid

13 Rauws EAJ, Langeberg W, Houthoff $\mathrm{HJ}$, Zanen HC, Tytgat gastritis: A prospective study of its prevalence and the effect. Radioimmunoassay of gut regulatory peptides. Iondon

15 Samloff IM. Pepsinogens I and II: purification from gastric 
breath test for Helicobacter pylori: comparison with histology, culture and ELISA histology. Gut 1991; 32: 1461-4.

17 Dill S, Payne-James JJ, Misiewicz JJ, Gribble GK McSwiggan D, Pathak K, et al. Evaluation of ${ }^{12} \mathrm{C}$-urea breath test in the detection of Helicobacter pylori and in monitorin the effect of tripotassium dicitratobismuthate in non-ulcer dyspepsia. Gut 1990; 31: 1237-41

18 Prewett EJ, Luk YW, Fraser AG, Lam WM, Pounder RE Comparison of one day dosing with three differents formulations of bismuth compounds. Aliment Pharmacol Ther 1992; 6: 97-102.

19 Lacy LF, Frazer NM, Keene ON, Smith JTL. Bismuth pharmacokinetics in healthy male subjects after twice daily oral dosing for 10 days with ranitidine bismuth citrate, tripotassium dicitrato bismuthate (DeNoltab), or placebo. Gut 1991; 32: A 1217

20 Nwokolo CU, Gavery CJ, Smith JTL, Pounder RE. The absorption of bismuth from oral doses of tripotassium absorption of bismuth from oral doses of tripotassium dicitrato.

21 Graham DY, Klein PD, Evans DJ, Evans DG, Alpert LC, Opekun AR, et al. Campylobacter pyloridis detected noninvasively by the ${ }^{13} \mathrm{C}$-urea breath test. Lancet 1987 ; i: $1174-7$.

22 Weil J, Bell GD, Jones PH, Grant P, Trowell JE, Harvison G. 'Eradication' of Campylobacter pylori: are we being misled? Lancet 1988 ii: 1245.

23 Chittajallu RS, Neithercut WD, MacDonald AMI, McColl production by urea infusion on plasma gastrin concentration. Gut 1991; 32: 21-4.

24 El Nujumi AM, Dorrian CA, Chittajallu RS, Neithercut WD McColl KEL. Effect of inhibition of Helicobacter pylor urease activity by acetohydroxamic acid on serum gastrin in urease activity by acetohydroxamic acid on serum

25 Wyatt JI, Rathbone BJ, Green DM, Primrose J. Raised fasting serum gastrin in chronic gastritis is independent of Campylobacter pylori status and duodenal ulceration. Gut 1989; 30 A1482.

26 Lanza FL, Skoglund ML, Rack MF, Yardley JH. The effect of bismuth subsalicylate on the histologic gastritis seen with Campylobacter pylori: A placebo-controlled, randomised study. Am J Gastroenterol 1989; 84: 1060-4.
27 McNulty CA, Gearty JC, Crump B, Davis M, Donovan IA, Melikian V. Campylobacter pyloridis and associated gastritis: Investigator-blind placebo-controlled trial of bismuth subsalicylate and erythromycin ethylsuccinate. BMF 1986;293: 645-9.

28 Marshall BJ, Armstrong JA, Francis GJ, Nokes NT, Wee SH. Antibacterial action of bismuth in relation to Campylobacter pvloridis colonization and gastritis. Digestion 1987; 37: (supp 2): $16-30$.

29 Chittajallu RS, Dorrian CA, Neithercut WD, Dahill S, McColl KEL. Is Helicobacter pylori associated hypergastrinaemia due to the bacterium's urease activity or the antral gastritis. Gut 1991; 32: 1286-90.

30 Valle J, Seppala K, Sipponen P, Kosonen T. Disappearance of gastritis after eradication of Helicobacter pylori: a morphogastritis after eradication of Helicobacter pylori: a morph

31 Jansen JB, Klinkenberg-Knol EC, Meuwissen GM, Bruiin JW, Festen HP, Snel P, et al. Effect of long-term treatmen with omeprazole on serum gastrin and serum group $A$ and $C$ pepsinogens in patients with reflux oesophagitis. Gastroenterology 1990; 99: 621-8.

32 McColl KEL, Nujumi AM, Dorrian CA, MacDonald AMI Fullarton GM, Harwood J. Helicobacter pylori and hypergastrinaemia during proton pump inhibitor therapy. $S$ cand $f$ Gastroenterol 1992; 27: 93-8.

33 Waldum HL, Straume BK, Burhol PG. Radioimmunoassay of group I pepsinogens (PGI) and the effect of food on serum PGI. Scand 7 Gastroenterol 1979; 14: 241-7.

34 Samloff IM, Varis K, Ihamaki T, Siurala $M$, Rotter JI. Relationships among serum pepsinogen I, serum pepsinogen II and gastric mucosal histology. Gastroenterology 1982; 83: II and

35 Young GO, Stemmet N, Lastovica A, Van der Meere E, Louw JA, Modlin IM, et al. Helicobacter pylori lipopolysaccharid stimulates gastric mucosal pepsinogen synthesis. Alimen Pharmacol Ther 1992; 6: 169-78.

36 McColl KEL, Fullarton GM, Chitlajallu RS, El Nujumi AM, MacDonald AMI, Dahill SW, et al. Plasma gastrin daytime intragastric $\mathrm{pH}$ and nocturnal acid output before and at and 7 months after eradication of Helicobacter pylori in duodenal ulcer subjects. Scand $\mathcal{7}$ Gastroenterol 1991; 26 : $339-46$. 